\title{
Multifunctional Nanocomposite Films for Synergistic Delivery of bFGF and BMP-2
}

\author{
Wei Qi,*il Jing Yan, Haifeng Sun, and Hua Wang*(-) \\ College of Chemistry and Chemical Engineering, Qufu Normal University, No. 57 Jingxuan West Road, Qufu, Shandong 273165, \\ China
}

\section{Supporting Information}

\begin{abstract}
The development of novel materials capable of delivering multiple growth factors is urgent and essential for rapid and effective tissue regeneration. In this study, a kind of composite film composed of poly-L-lysine (PLL), heparin (Hep), and Au nanoparitcles (Au nps) has been fabricated to deliver the basic fibroblast growth factor (bFGF) and bone morphogenetic protein-2 (BMP-2) simultaneously. The films have been found to show enhanced mechanical property due to the incorporation of Au nps. They have also shown good anticoagulation activity with long activated partial thromboplastin time because of the contribution of Hep molecules. Moreover, the osteogenesis studies reveal that the loaded bFGF and BMP-2 in the composite films have a synergistic differentiation effect on mesenchymal stem cells, as indicated by alkaline phosphatase (ALP) activity assay and collagen type I (Col-I) gene expression. In contrast to the (PLL/Hep) ${ }_{6} / \mathrm{BMP}-2 /(\mathrm{PLL} / \mathrm{Au}$ nps $)_{6} /(\mathrm{PLL} / \mathrm{Hep})_{6}$ and (PLL/Hep $)_{6} /(\mathrm{PLL} / \mathrm{Au} \mathrm{nps})_{6} /(\mathrm{PLL} / \mathrm{Hep})_{6} / \mathrm{bFGF}$ films, the (PLL/ Hep $)_{6} / \mathrm{BMP}-2 /(\mathrm{PLL} / \mathrm{Au} \text { nps })_{6} /(\mathrm{PLL} / \mathrm{Hep})_{6} / \mathrm{bFGF}$ films have shown higher ALP activity and higher Col-I expression level. Therefore, the developed multifunctional films could be potentially used as osteoinductive coatings of biomaterials. Particularly, this simple and convenient strategy provides an effective approach for the immobilization of multiple growth factors, which may be extended to other bioactive systems for the development of novel multifunctional bioactive surfaces.
\end{abstract}

\section{INTRODUCTION}

Growth factors refer to naturally occurring proteins capable of targeting specific cellular receptors and triggering various cellular processes. ${ }^{1-3}$ They have generated numerous clinical trials and are of great interest in regeneration medicine and tissue engineering. However, there are still some challenges to the use of growth factors such as high cost, easy denaturation, short biological half-life, rapid local clearance by circulation, and potential side effects in supra-physiological dosage. ${ }^{4-6}$ Therefore, many researchers have focused on the investigation of localized delivery systems that can offer the potential of concentrating them and of protecting them from denaturation. $^{7-9}$

Particularly, glycosaminoglycan-containing biomaterials have become an attractive delivery method for growth factors due to the specific binding affinity between them. Among these glycosaminoglycans, heparin (Hep), a negatively charged polysaccharide, is especially attractive because of its high content of sulfate groups in the polymer chains. It has been shown to have strong affinities for a class of growth factors, such as the basic fibroblast growth factor (bFGF), vascular endothelial growth factor, transforming growth factor $\beta$, and bone morphogenetic protein (BMP) ${ }^{10}$ In addition to the localized delivery of a single factor, simultaneous or sequential delivery of multiple growth factors has also been studied for the enhancement of therapeutic efficiency. ${ }^{11,12}$ However, embedding Hep in delivery systems often leads to chemical or conformational variation of the structure, resulting in a loss of the inherent activity of Hep. ${ }^{13}$ Therefore, the development of novel systems is highly required to efficiently encapsulate growth factors as well as to minimize the loss of Hep activity. Layer-by-layer (LbL) assembled systems could be potential candidates due to the fact that a large variety of biological objects have been deposited without denaturation, including lipids, proteins, bacteria, viruses, and so on. ${ }^{14-17}$

In the last two decades, the LbL assembly has become a convenient method for fabricating multilayer films, regardless of the dimension and topography of the substrates. The method provides simplicity, versatility, and nanoscale control, making it one of the most widely used technologies for surface functionalization in many fields, especially in cellular and tissue engineering. ${ }^{18-25}$

In this study, Hep was assembled by the LbL assembly technique using poly-L-lysine (PLL), a positively charged polypeptide, with simultaneous immobilization of bFGF and BMP-2. bFGF is a well-known growth factor, which exerts stimulatory effects on the migration and proliferation of various types of cells, such as vascular cells and osteoblasts, and has been recognized as an important growth factor in the process of bone fracture healing. ${ }^{26} \mathrm{BMP}-2$ is the most potent growth

Received: November 23, 2016

Accepted: January 18, 2017

Published: March 14, 2017 
factor for bone regeneration by stimulating the migration of mesenchymal stem cells (MSCs) and their differentiation into osteoblasts. $^{26}$ The effects of the films delivering bFGF and BMP-2 dually and those delivering bFGF or BMP-2 singly on the osteogenic differentiation of MSCs were evaluated via alkaline phosphatase (ALP) staining, ALP activity assay, and collagen type I (Col-I) gene expression.

As a potential candidate for applications in bone regeneration and bone tissue engineering, the growth of thrombus must be suppressed on the surface of Hep. Interestingly, besides immobilizing growth factors, Hep could also inhibit the formation of thrombus. Hep is an important anticoagulant in clinics for the treatment of venous thromboembolism. It has an effect on inhibiting the activation of prothrombin in normal plasma and preventing the thrombus formation by catalytically accelerating the affinity of AT III to thrombin. ${ }^{27}$ The activated partial thromboplastin time (APTT) tests, as the medical tests that characterize blood coagulation, were performed on all heparined films in this study to evaluate their anticoagulation properties.

Additionally, $\mathrm{Au}$ nanoparticles (Au nps) were incorporated into the PLL/Hep films to enhance the mechanical property of the pure polymer films based on our previous reports that the mechanical properties of polymer films could be enhanced by introducing high-strength nanomaterials into the polymer matrix. ${ }^{28,29}$ Moreover, there has been accumulating evidence that Au nps can facilitate stem cell therapy and bone tissue engineering due to their distinct physicochemical properties, excellent biocompatibility, facile synthesis, and easy surface modification. ${ }^{30-33}$ In addition, considering that the mechanical strength is a concern parameter regulating biological processes and even determining cell fate, ${ }^{34-37}$ the mechanical properties of the polymer films and the composite films were all measured by the nanoindentation technique and compared in this study.

Thus, the functional assembled multilayer of (PLL/Hep $)_{6} /$ $\mathrm{BMP}-2 /(\mathrm{PLL} / \mathrm{Au} \text { nps })_{6} /(\mathrm{PLL} / \mathrm{Hep})_{6} / \mathrm{bFGF}$ (Figure 1) is anticipated to inhibit thrombus formation, enhance mechanical properties and promote osteogenic differentiation of MSCs.

\section{RESULTS AND DISCUSSION}

Characterization of Au nps. The Au nps were fabricated with citrate reduction, which has become a model system. The particles obtained by this method were always well dispersed and the size of the particles could be controlled by adjusting the $\mathrm{Na}_{3} \mathrm{C}_{6} \mathrm{H}_{5} \mathrm{O}_{7} / \mathrm{HAuCl}_{4}$ ratio. ${ }^{38,39}$ From the TEM images (Figure $\mathrm{S} 1 \mathrm{~A}$ ), the obtained monodispersed $\mathrm{Au}$ nps were estimated to have a diameter of $17 \mathrm{~nm}$. The UV-vis peak at $522 \mathrm{~nm}$ is shown in Figure S1B, where the surface plasmon resonance (SPR) indicated particle sizes between 15 and $20 \mathrm{~nm}$. Dynamic light scattering (DLS) measurements confirmed that the average diameter of $\mathrm{Au}$ nps was about $18 \mathrm{~nm}$ (Figure S1C). These results were consistent with each other. Additionally, the zeta potential of the Au nps was determined to be $-31.5 \mathrm{mV}$, which is convenient for the subsequent assembly with positively charged species.

Characterization of Au np-Based Multilayer Films. The negatively charged $\mathrm{Au}$ nps were assembled with PLL, the positively charged polypeptide, using the LbL assembly technique. Firstly, the (PLL/Au nps) ${ }_{2}$ films were assembled onto silicon wafers for X-ray photoelectron spectroscopy (XPS) analysis. Chemical element composition of the films could be reflected from the XPS spectrum. According to the scienta ESCA 300 database, $^{40}$ the peaks of Au $4 \mathrm{f}$ at $87.7 \mathrm{eV}$ and $\mathrm{N}$ 1s at
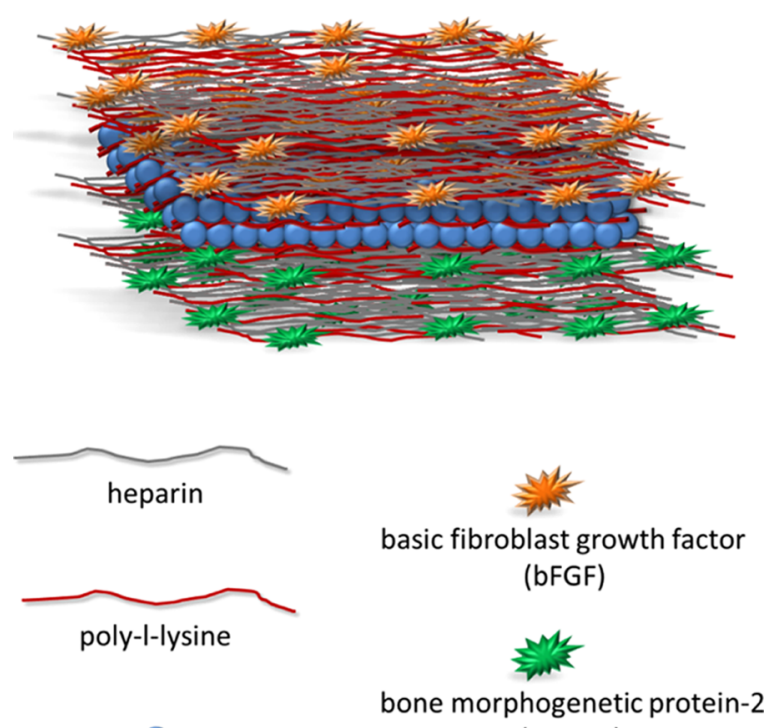

(BMP-2)

Au nanoparticles

Figure 1. Schematic representation of the construction of the nanocomposite films (PLL/Hep) 6 / BMP-2/(PLL/Au nps) 6 /(PLL/ Hep $)_{6} /$ bFGF for co-delivery of growth factors. Au nps: $\mathrm{Au}$ nanoparticles; PLL: poly-L-lysine; Hep: heparin; BMP-2: bone morphogenetic protein-2; bFGF: basic fibroblast growth factor.

$400 \mathrm{eV}$ in Figure 2A confirmed that $\mathrm{Au}$ nps and PLL were assembled onto the silicon wafer successfully. However, the peak at $152 \mathrm{eV}$ for Si $2 \mathrm{~s}$ implied that the (PLL/Au nps) ${ }_{2}$ film had not covered the whole silicon wafer surface. Thus, the twobilayer film was not enough to form a coherent coating, showing the necessity to build films with more layers. The construction of the PLL/Au nps films with different bilayers, from one to six bilayers, was monitored by the UV-vis spectra, as shown in Figure 2B. In contrast to bare Au nps, redshifts of SPR of $\mathrm{Au}$ nps in the films were obvious for one bilayer, two bilayers, and three bilayers, from 521 to 595, 644, and 663, respectively. The shift almost vanished from three bilayers until six bilayers. According to the study of the Tsukruk group, ${ }^{41}$ the redshifts might be caused by interparticle resonances, which could be decided by the distance/diameter ratio of Au nps in the films. Furthermore, both the surface morphology of the (PLL/Au nps) ${ }_{6}$ and the (PLL/Hep) ${ }_{6}$ ultrathin films could be observed with the atomic force microscopy (AFM) technique (Figure 2C,D). In total, $5 \times 5 \mu \mathrm{m}^{2}$ images of the layers of interest were collected and recorded. Obviously, Au nps were deposited by forming a nanostructured surface with some aggregates of nanoparticles on it, as in Figure 2C. Compared to the pure polymer films (PLL/Hep), the nanostructured surface exhibited a roughness of $22.87 \mathrm{~nm}$ (Rms), whereas the former showed a roughness of $3.70 \mathrm{~nm}$ (Rms).

Here, Au nps were incorporated into the films to obtain films with excellent mechanical properties. The mechanical property of the developed PLL/Au np films together with PLL/Hep films was determined by the TriboIndenter nanomechanical test technique. The technique allows a direct measurement of the mechanical properties of films. A maximum load of $12 \mu \mathrm{N}$ was applied on the films, and to avoid substrate effects, the depth of indentation was kept below $20 \%$ of the film thickness. Considering this, 180 bilayers of the films were prepared for mechanical measurements. The obtained load-displacement $(P-h)$ curves of both $\left[(\mathrm{PLL} / \mathrm{Hep})_{6} /(\mathrm{PLL} / \mathrm{Au} \mathrm{nps})_{6} /(\mathrm{PLL} /\right.$ 
A
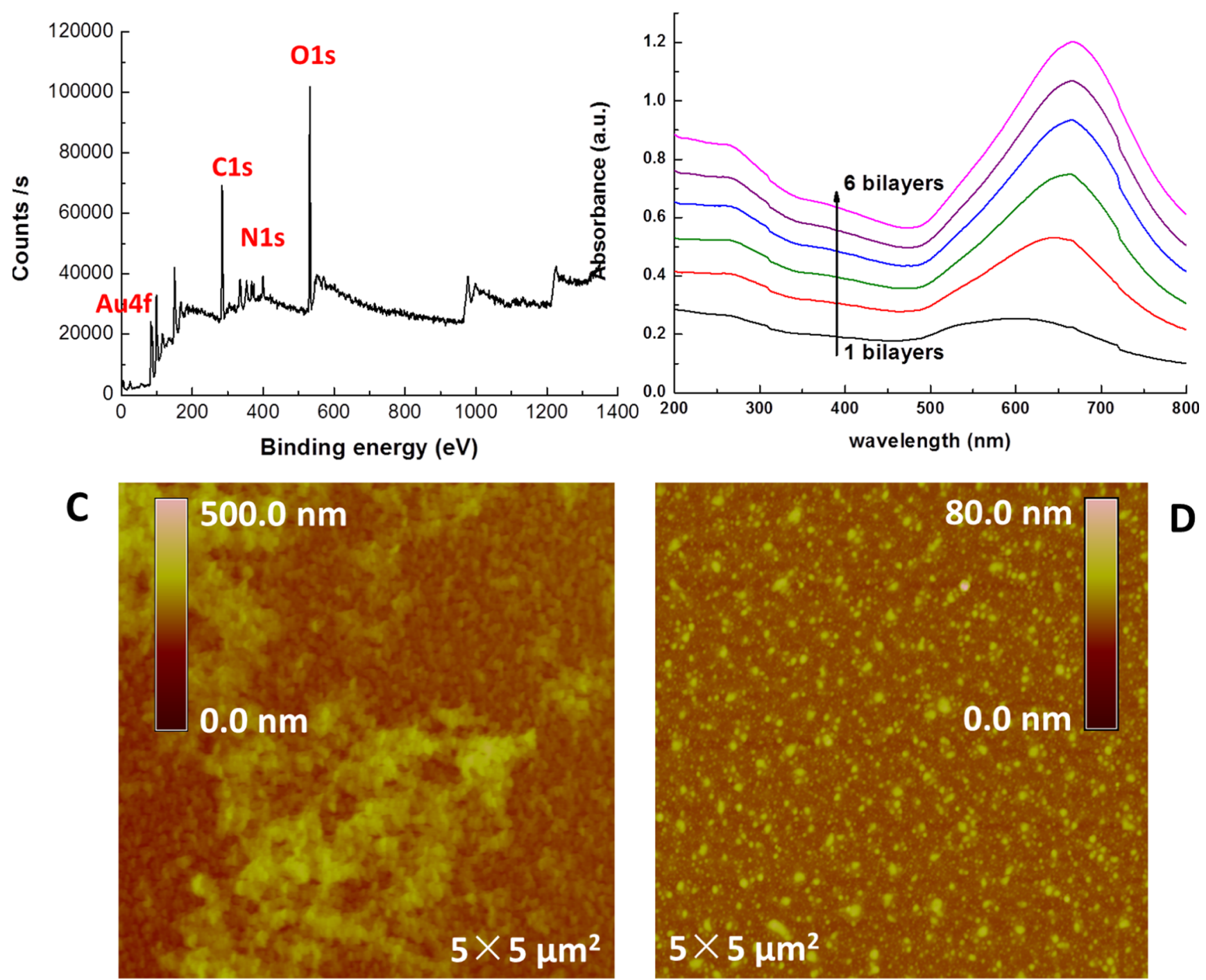

Figure 2. (A) XPS analysis of the (PLL/Au nps) ${ }_{2}$ films. (B) UV-vis spectra of the PLL/Au nps films with different bilayers, with one to six bilayers shown from bottom to top. AFM images of (C) the (PLL/Au nps) ${ }_{6}$ film and (D) the (PLL/Hep) ${ }_{6}$ film.

Hep $\left.)_{6}\right]_{10}$ films and (PLL/Hep) ${ }_{180}$ films are shown in Figure $3 \mathrm{~A}$. From the figure, a change in the unloading gradient between two kinds of films could be clearly observed. This indicated an increase in the reduced elastic modulus $\left(E_{\mathrm{r}}\right)$ from PLL/Hep films to PLL/Au nps films, which could be calculated to be 7.81 $\pm 0.82 \mathrm{GPa}$ for the PLL/Au nps films and $0.18 \pm 0.07 \mathrm{GPa}$ for the PLL/Hep films with the Oliver-Pharr model (Figure 3B). Likewise, the maximum indentation depth $\left(h_{\max }\right)$ of the composite films is shorter than that of the pure films, indicating that the films are harder to penetrate than the latter under the same indentation load. The hardness $(H)$ of the films is also shown in Figure 3B, that is, $145 \pm 16 \mathrm{MPa}$ for the nanocomposite films and $6.8 \pm 1.95 \mathrm{MPa}$ for the pure polymer films. Actually, the values of $E_{\mathrm{r}}$ and $H$ vary according to the measurement method and physical model, so the values here are the comparative ones based on the nanoindentation technique and the Oliver-Pharr model, but still, these results could serve as the evidence that the mechanical properties of the polymer films were enhanced substantially by incorporation of Au nps. It has been found that human MSCs could be directed along neuronal, muscle, or bone lineages by changing the stiffness of the substrate. ${ }^{35}$ For example, Discher et al. have reported that soft matrices that mimic brain could induce neurogenic differentiation of hMSCs, stiffer matrices that mimic muscle were myogenic, and comparatively rigid matrices that mimic collagenous bone induced osteogenic differentiation. ${ }^{36}$ Accordingly, the comparatively rigid $\mathrm{Au} \mathrm{np}$-based films could have the potential to induce osteogenic differentiation of MSCs.

Loading and Releasing of Growth Factors. On the surface of the (PLL/Hep) 6 films, BMP-2 and bFGF bind with the Hep molecules. The binding affinity and process were investigated with a quartz crystal microbalance (QCM) using the third overtone (Figure 4). With the QCM technique, mass changes could be reflected from the resonant frequency shifts when interaction occurs on the surface of the electrode. In Figure 4A, a significant decrease in frequency is observed upon the exposure of the (PLL/Hep) 6 films to BMP-2 solution, meaning a strong binding of the films with BMP-2. Then the frequency decreased slowly with increasing interaction time and became stable after $3 \mathrm{~h}$ of interaction. A similar tendency for the bFGF immobilization could be observed in the (PLL/ 

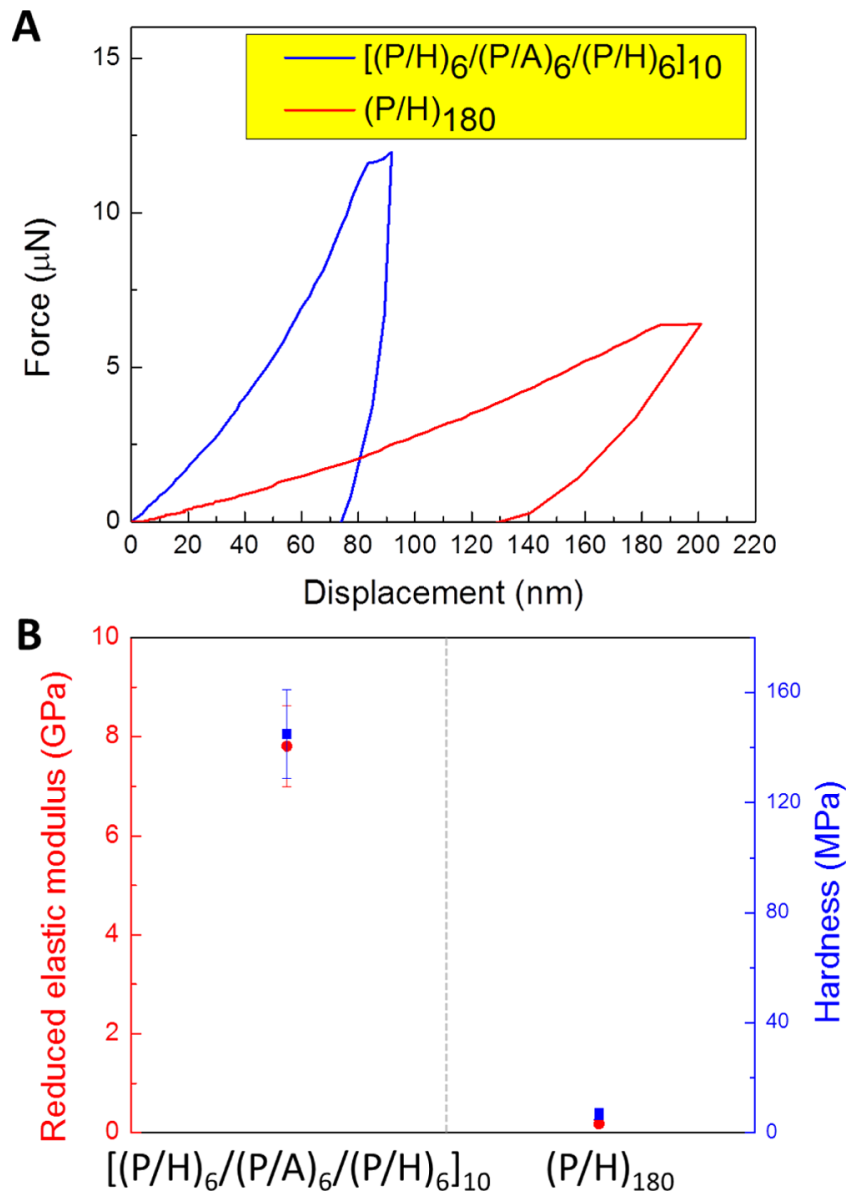

Figure 3. (A) Load-displacement curves of the $\left[(\mathrm{PLL} / \mathrm{Hep})_{6} /(\mathrm{PLL} /\right.$ $\mathrm{Au}$ nps $\left.)_{6} /(\mathrm{PLL} / \mathrm{Hep})_{6}\right]_{10}$ films and (PLL/Hep) $)_{180}$ films obtained using the nanoindentation technique. (B) Values of the reduced elastic modulus $\left(E_{\mathrm{r}}\right)$ and hardness $(H)$ of the composite film and the polymer film. The error bars are all standard deviation (SD).

Hep) 6 films (Figure 4B). The subsequent washing step with PBS did not bring about any significant frequency increase, which means the strong immobilization of growth factors on the film. Therefore, the as-developed films could immobilize and load multiple growth factors simultaneously and efficiently. In the case of BMP-2 immobilization (Figure 4A), the subsequent deposition of PLL and Au nps was also monitored with QCM. Obviously, further upper layer assembly caused new frequency decreases, thus indicating continuous assembly on the former film.

We further examined the dynamics of bFGF and BMP-2 released from (PLL/Hep) $)_{6} /(\mathrm{PLL} / \mathrm{Au} \text { nps })_{6} /(\mathrm{PLL} / \mathrm{Hep})_{6} /$ $\mathrm{bFGF}$ and (PLL/Hep) ${ }_{6} / \mathrm{BMP}-2 /\left(\mathrm{PLL} / \mathrm{Au}\right.$ nps) ${ }_{6} /(\mathrm{PLL} /$ Hep $)_{6}$, respectively. The release profiles are listed in Figure 5. It could be seen that both systems showed sustained release of the growth factors over an incubation period of 21 days. These release behaviors are decided mainly by the interactions between the growth factors and Hep molecules in the films, which delayed their diffusion into the incubation media. Compared with the release of bFGF, that of BMP-2 seemed much slower during the entire process. After the incubation of 21 days, nearly about $70 \%$ of the loaded bFGF and $40 \%$ of that of BMP-2 were released. It might be assumed that the dual physical blocking contributed by $\mathrm{Au}$ nps and the macromolecule multilayer film limited the diffusion of BMP-2.
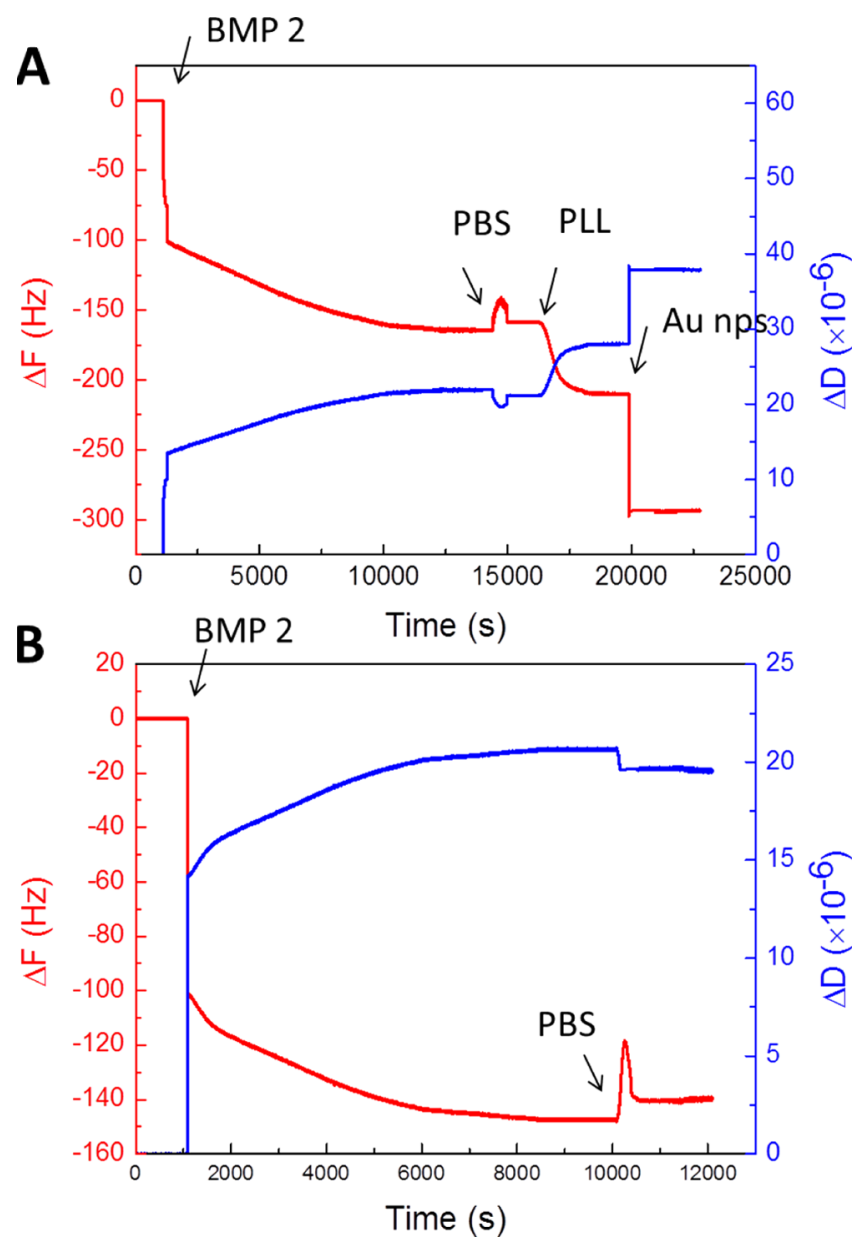

Figure 4. (A) QCM curves showing changes in frequency during the interaction of the (PLL/Hep) $)_{6}$ films with BMP-2 in PBS $(200 \mathrm{ng} / \mathrm{mL})$ and the subsequent steps, including the washing process with PBS and the deposition of PLL and Au nps; (B) that of (PLL/Hep) 6 with bFGF solution $(200 \mathrm{ng} / \mathrm{mL})$ and the washing process with PBS.

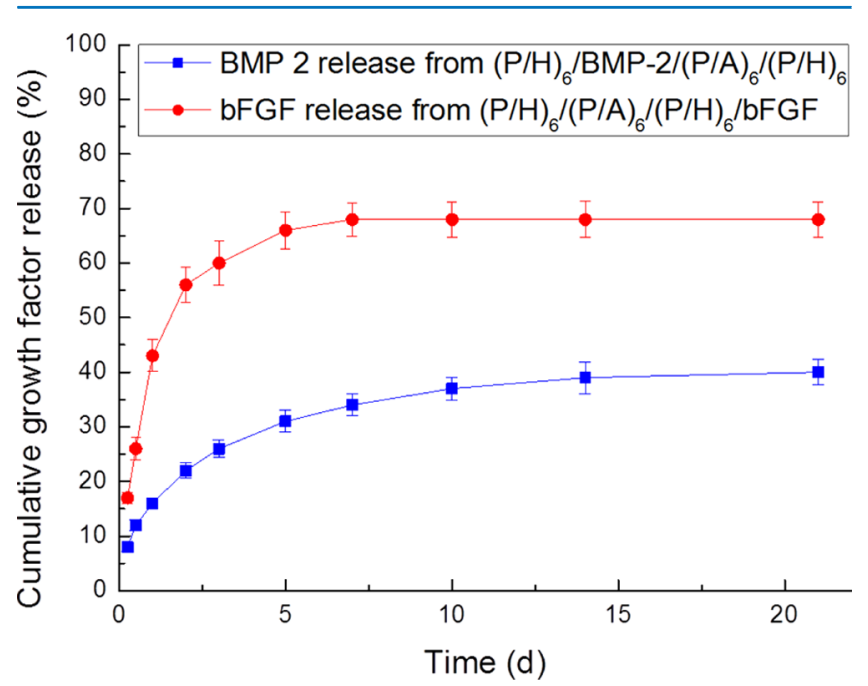

Figure 5. In vitro release profiles for BMP-2 and bFGF from (PLL/ Hep $)_{6} / \mathrm{BMP}^{2} 2 /(\mathrm{PLL} / \mathrm{Au} \text { nps })_{6} /(\mathrm{PLL} / \mathrm{Hep})_{6}$ and (PLL/Hep) $)_{6} /(\mathrm{PLL} /$ Au nps $)_{6} /(\mathrm{PLL} / \mathrm{Hep})_{6} / \mathrm{bFGF}$, respectively. The error bars are all SD.

Anticoagulation Properties of the Heparined Multilayers. The in vitro anticoagulation properties of the materials were commonly evaluated using an APTT assay. The APTT 
A
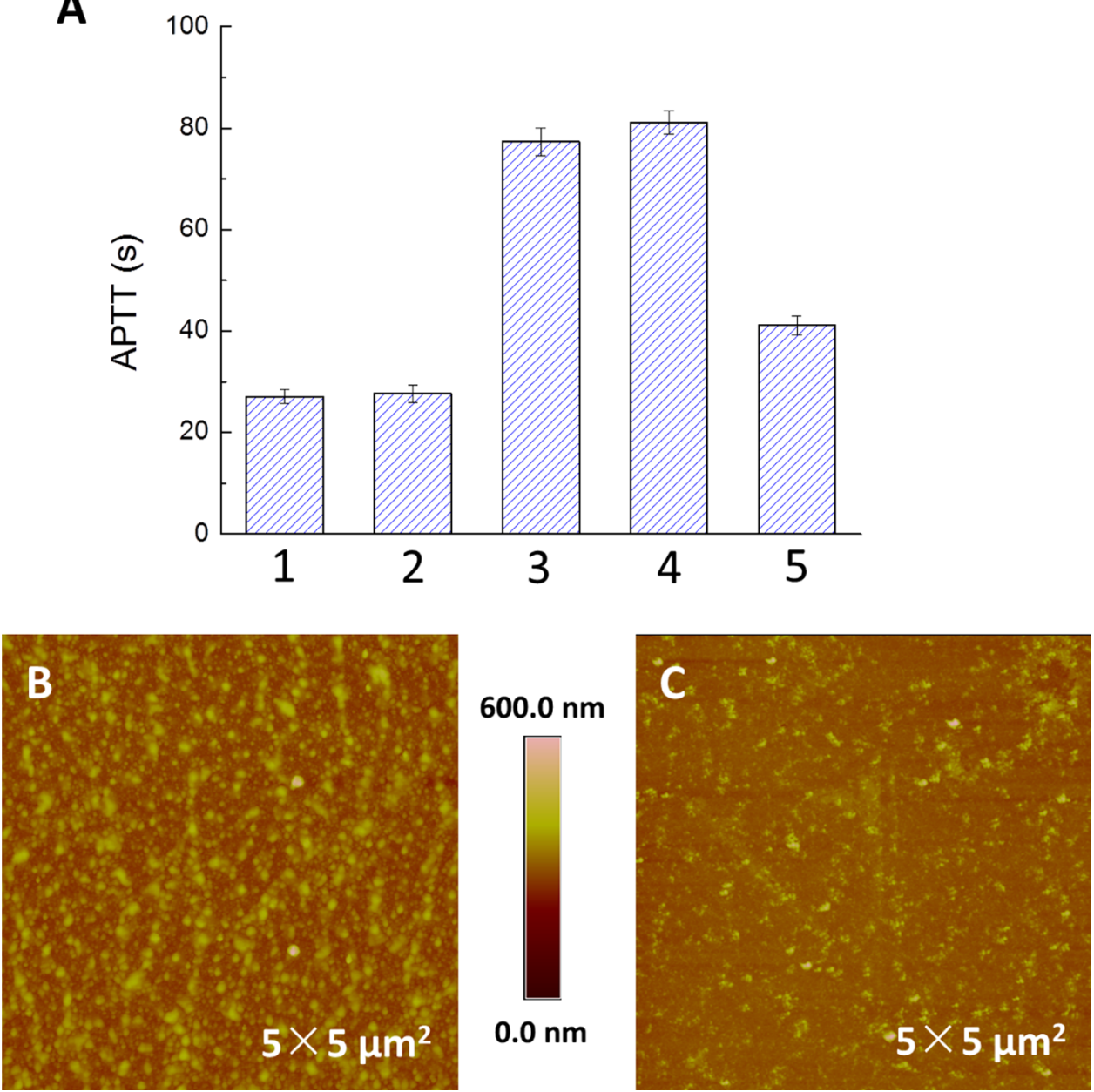

Figure 6. (A) APTT values of (1) PRP; (2) PLA sheets; (3) PLA-(PLL/Hep) ${ }_{18}$; (4) PLA-(PLL/Hep) 6 /(PLL/Au nps) 6 /(PLL/Hep) $)_{6}$ and (5) $(\mathrm{PLL} / \mathrm{Hep})_{6} / \mathrm{BMP}-2 /(\mathrm{PLL} / \mathrm{Au} \mathrm{nps})_{6} /(\mathrm{PLL} / \mathrm{Hep})_{6} / \mathrm{bFGF}$. The error bars are all SD. AFM morphology image of (B) (PLL/Hep) $6 /(\mathrm{PLL} / \mathrm{Au}$ nps $)_{6} /(\mathrm{PLL} / \mathrm{Hep})_{6}$ and (C) (PLL/Hep $)_{6} / \mathrm{BMP}-2 /(\mathrm{PLL} / \mathrm{Au} \text { nps })_{6} /(\mathrm{PLL} / \mathrm{Hep})_{6} / \mathrm{bFGF}$.

values of the poly(lactic acid) (PLA) sheet, PLA-(PLL/Hep) ${ }_{18}$, $\mathrm{PLA}-(\mathrm{PLL} / \mathrm{Hep})_{6} /(\mathrm{PLL} / \mathrm{Au} \mathrm{nps})_{6} /(\mathrm{PLL} / \mathrm{Hep})_{6}$, and (PLL/ Hep $)_{6} / \mathrm{BMP}-2 /(\mathrm{PLL} / \mathrm{Au} \text { nps })_{6} /(\mathrm{PLL} / \mathrm{Hep})_{6} / \mathrm{bFGF}$ and that of the untreated platelet-rich plasma (PRP) as a control were all recorded and are compared in Figure 6A. There was little difference between the PLA sheet and PRP, with a value of 27.7 $\pm 1.7 \mathrm{~s}$, a normal coagulation time. However, the values of all of the heparined surfaces were prolonged to be $41.1 \pm 1.9 \mathrm{~s}$ for PLA-(PLL/Hep $)_{6} / \mathrm{BMP}-2 /(\mathrm{PLL} / \mathrm{Au} \text { nps })_{6} /(\mathrm{PLL} / \mathrm{Hep})_{6} /$ bFGF, $77.3 \pm 2.9$ and $81.1 \pm 2.4 \mathrm{~s}$ for PLA-(PLL/Hep) $)_{18}$ and PLA-(PLL/Hep $)_{6} /(\mathrm{PLL} / \mathrm{Au} \mathrm{nps})_{6} /(\mathrm{PLL} / \mathrm{Hep})_{6}$, respectively. These results could be attributed to the contribution of Hep molecules. Moreover, compared with the other heparined surfaces, the (PLL/Hep) ${ }_{6} / \mathrm{BMP}-2 /(\mathrm{PLL} / \mathrm{Au} \mathrm{nps})_{6} /(\mathrm{PLL} /$ Hep $)_{6} /$ bFGF surface had a shorter coagulation time, which might be due to the blocking of growth factors immobilized in the films. In fact, the decreased anticoagulation activity is more desirable because of some excessive bleeding side effects from very high anticoagulation activity. ${ }^{42}$ Additionally, the surface morphology images of (PLL/Hep $)_{6} /(\mathrm{PLL} / \mathrm{Au} \mathrm{nps})_{6} /(\mathrm{PLL} /$ $\mathrm{Hep})_{6}$ and (PLL/Hep) $)_{6} / \mathrm{BMP}-2 /(\mathrm{PLL} / \mathrm{Au} \text { nps })_{6} /(\mathrm{PLL} /$ $\mathrm{Hep})_{6} / \mathrm{bFGF}$ were recorded with AFM (Figure 6B,C). There was a slight difference in the surface roughness between them, $3.29 \mathrm{~nm}$ for the former and $1.33 \mathrm{~nm}$ for the latter.
Cytotoxicity Assay of the Developed Nonallanocomposite Films. Rat bone marrow derived MSCs were cultured on all of the studied surfaces, including tissue culture polystyrene (TCPS), PLA sheets, PLA-(PLL/Hep) ${ }_{6} / \mathrm{BMP}-2 /$ (PLL/Au nps $)_{6} /(\mathrm{PLL} / \mathrm{Hep})_{6}, \mathrm{PLA}-(\mathrm{PLL} / \mathrm{Hep})_{6} /(\mathrm{PLL} / \mathrm{Au}$ nps $)_{6} /(\mathrm{PLL} / \mathrm{Hep})_{6} / \mathrm{bFGF}$, and PLA-(PLL/Hep $)_{6} / \mathrm{BMP}-2 /$ (PLL/Au nps $)_{6} /(\mathrm{PLL} / \mathrm{Hep})_{6} / \mathrm{bFGF}$. Phase-contrast images of all of these MSCs cultured for 3 days were obtained using an Olympus microscope (Figure 7A). The MSCs were found to spread on the surfaces, exhibiting a shuttle-shaped appearance in a whirlpool manner. They were polygonal and flattened with the elongated structure with their spindle-like shape. These results suggested that the developed surfaces had not hampered normal growth of the cells. On the other hand, cell viability was investigated by CCK- 8 assay when the cells were cultured in normal cell medium on all of the studied surfaces (Figure 7B) at days $1,7,14$, and 21 . It could be seen that there was no significant difference in cell survival and proliferation between the developed surfaces and the controls (Figure S2), which indicated that the developed films had low cytotoxicity and were promising for applications in cellular and tissue engineering.

Osteogenic Differentiation of MSCs on the Developed Nanocomposite Films'. ALP Activity. MSCs have multiple differentiation capacity and could be induced osteogenic 

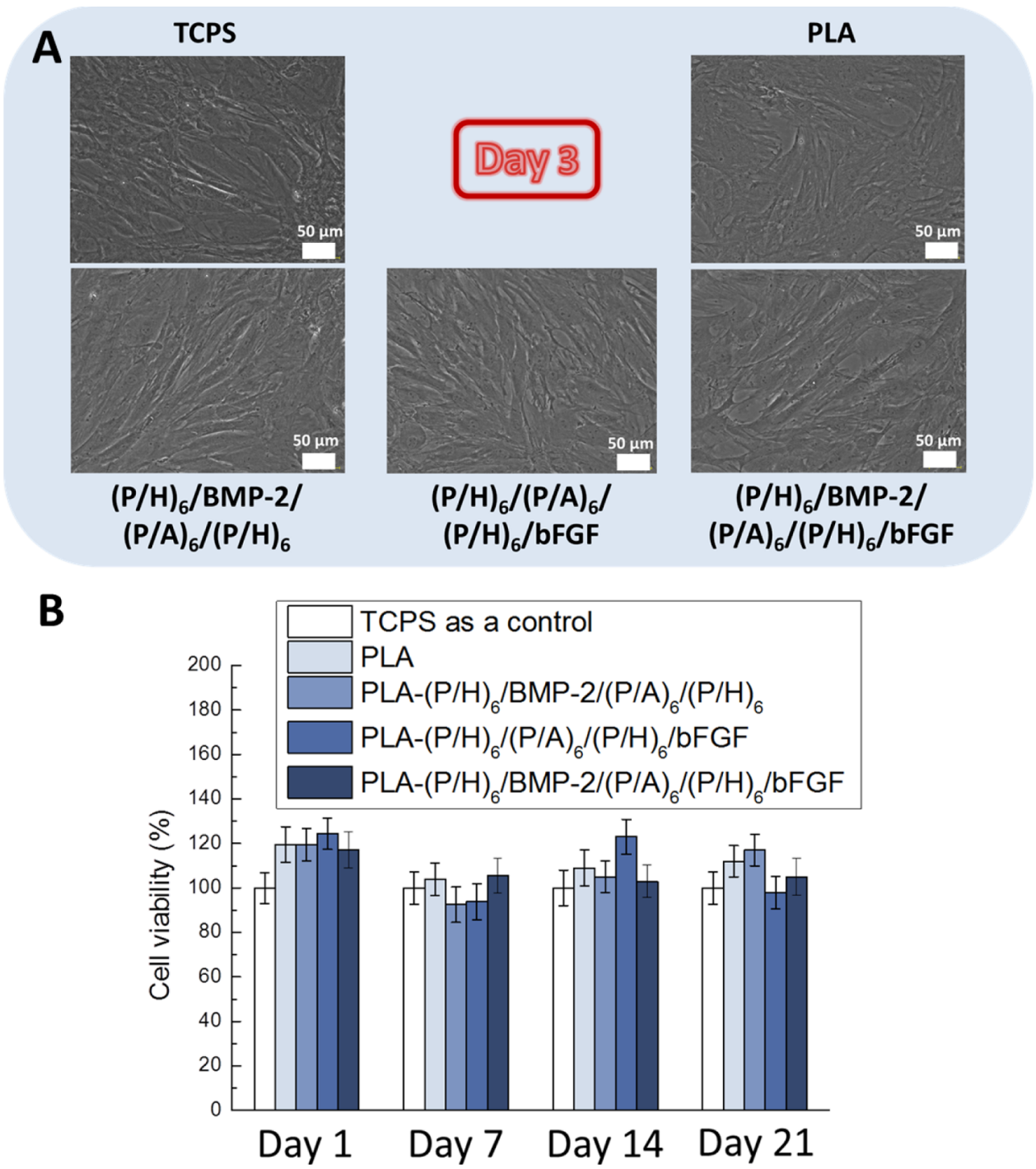

Figure 7. (A) Phase-contrast images of MSCs cultured on TCPS, PLA, PLA-(PLL/Hep) ${ }_{6} /$ BMP-2/(PLL/Au nps) $6 /(\text { PLL/Hep })_{6}$, PLA-(PLL/ $\mathrm{Hep})_{6} /(\mathrm{PLL} / \mathrm{Au} \text { nps })_{6} /(\mathrm{PLL} / \mathrm{Hep})_{6} / \mathrm{bFGF}$, and PLA-(PLL/Hep $)_{6} / \mathrm{BMP}-2 /(\mathrm{PLL} / \mathrm{Au} \text { nps })_{6} /(\mathrm{PLL} / \mathrm{Hep})_{6} / \mathrm{bFGF}$ for 3 days. The scale bars are all $50 \mu \mathrm{m}$. (B) Cell viability of MSCs cultured on the above surfaces for 1, 7, 14, and 21 days. Those cultured on TCPS were used as controls. The error bars are all SD.

differentiation by specific growth factors. ALP activity is generally used as an early-stage marker of osteogenic differentiation. ALP staining and ALP activity assay were performed simultaneously to investigate the osteogenic differentiation of MSCs on all of the studied surfaces, including TCPS, PLA sheets, PLA-(PLL/Hep $)_{6} / \mathrm{BMP}-2 /(\mathrm{PLL} / \mathrm{Au}$ nps $)_{6} /(\mathrm{PLL} / \mathrm{Hep})_{6}$, PLA-(PLL/Hep $)_{6} /(\mathrm{PLL} / \mathrm{Au} \text { nps })_{6} /(\mathrm{PLL} /$ Hep $)_{6} / \mathrm{bFGF}$, and PLA-(PLL/Hep) ${ }_{6} / \mathrm{BMP}-2 /(\mathrm{PLL} / \mathrm{Au} \text { nps })_{6} /$ (PLL/Hep) $)_{6} / \mathrm{bFGF}$. Significantly enhanced ALP activity produced from MSCs on PLA-(PLL/Hep) 6 /BMP-2/(PLL/ $\mathrm{Au} n \mathrm{~ns})_{6} /(\mathrm{PLL} / \mathrm{Hep})_{6} / \mathrm{bFGF}$ could be observed both in the ALP staining (Figure $8 \mathrm{~A}$ ) and in the quantitative assay (Figure $8 \mathrm{~B})$. In Figure $8 \mathrm{~A}$, dark-blue staining in the cells cultured on PLA-(PLL/Hep $)_{6} / \mathrm{BMP}-2 /(\mathrm{PLL} / \mathrm{Au} \mathrm{nps})_{6} /(\mathrm{PLL} / \mathrm{Hep})_{6} /$ bFGF was more intense than those cultured on PLA-(PLL/ Hep $)_{6} / \mathrm{BMP}-2 /(\mathrm{PLL} / \mathrm{Au} \mathrm{nps})_{6} /(\mathrm{PLL} / \mathrm{Hep})_{6}$ and PLA-(PLL/ $\mathrm{Hep})_{6} /(\mathrm{PLL} / \mathrm{Au} \mathrm{nps})_{6} /(\mathrm{PLL} / \mathrm{Hep})_{6} / \mathrm{bFGF}$. This was consistent with the quantitative results of ALP activity, as shown in Figure 8B. ALP activity for all of the cells increased significantly from days 3 to 14 . The cells cultured on the (PLL/Hep) $)_{6} /$
BMP-2/(PLL/Au nps $)_{6} /(\mathrm{PLL} / \mathrm{Hep})_{6} / \mathrm{bFGF}$ films showed higher ALP activity than those on the (PLL/Hep) $)_{6} / \mathrm{BMP}-2 /$ $(\mathrm{PLL} / \mathrm{Au} \mathrm{nps})_{6} /(\mathrm{PLL} / \mathrm{Hep})_{6}$ and (PLL/Hep) ${ }_{6} /(\mathrm{PLL} / \mathrm{Au}$ nps $)_{6} /(\mathrm{PLL} / \mathrm{Hep})_{6} / \mathrm{bFGF}$ films. These results provided the evidence of the synergistic effect between BMP-2 and bFGF in the (PLL/Hep) ${ }_{6} / \mathrm{BMP}-2 /(\mathrm{PLL} / \mathrm{Au} \mathrm{nps})_{6} /(\mathrm{PLL} / \mathrm{Hep})_{6} / \mathrm{bFGF}$ films.

Col-I Gene Expression during Osteoinducive Differentiation. Osteogenic differentiation of MSCs would lead to increased expression of several osteogenic lineage genes, especially Col-I. The expression of Col-I gene was measured by real-time polymerase chain reaction (RT-PCR) for cells cultured on all studied surfaces at days 3, 7, 14, and 21 of differentiation induction (Figure 9). The results were presented as the ratio of Col-I to GADPH for each system, with glyceraldehyde 3-phosphate dehydrogenase (GAPDH) as the internal control. The mRNA expression levels of Col-I for all of the induced groups increased steadily from day 3 , reached the highest at day 7 or 4 , followed by significant decrease till day 21. The cells on the (PLL/Hep) ${ }_{6} / \mathrm{BMP}-2 /(\mathrm{PLL} / \mathrm{Au} \text { nps })_{6} /$ 


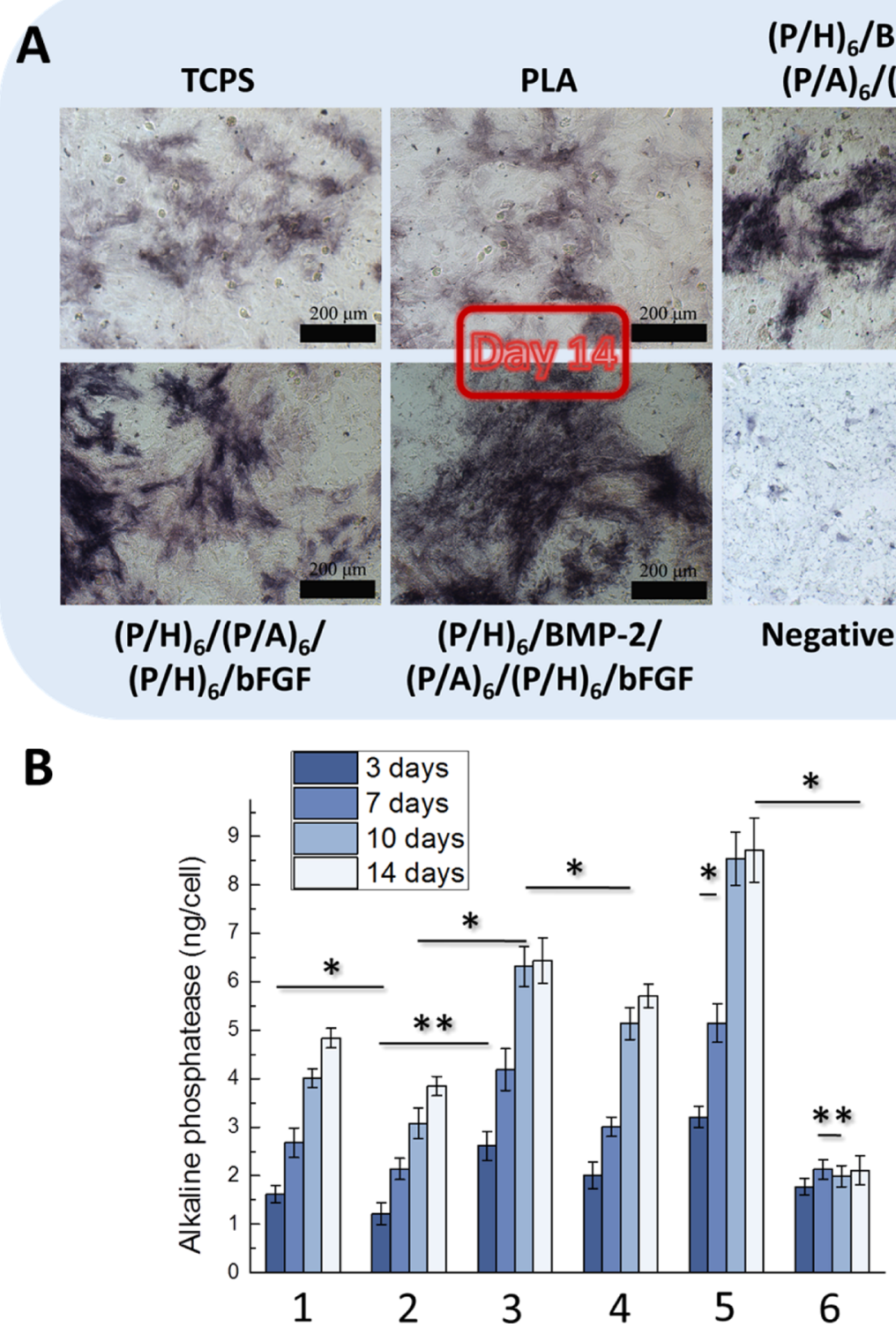

Figure 8. (A) ALP staining images of MSCs cultured on TCPS, PLA, PLA-(PLL/Hep $)_{6} / \mathrm{BMP}-2 /(\mathrm{PLL} / \mathrm{Au} \text { nps })_{6} /(\mathrm{PLL} / \mathrm{Hep})_{6}$, PLA-(PLL/Hep) 6 (PLL/Au nps $)_{6} /(\mathrm{PLL} / \mathrm{Hep})_{6} / \mathrm{bFGF}$, and PLA-(PLL/Hep $)_{6} / \mathrm{BMP}-2 /(\mathrm{PLL} / \mathrm{Au} \mathrm{nps})_{6} /(\mathrm{PLL} / \mathrm{Hep})_{6} / \mathrm{bFGF}$ and negative control for 14 days. The scale bars are all $200 \mu \mathrm{m}$. (B) ALP activity of MSCs cultured on 1: TCPS; 2: PLA; 3: PLA-(PLL/Hep) $)_{6} / \mathrm{BMP}-2 /\left(\mathrm{PLL} / \mathrm{Au}\right.$ nps) ${ }_{6} /(\mathrm{PLL} / \mathrm{Hep})_{6}$; 4 : PLA-(PLL/Hep) ${ }_{6} /\left(\mathrm{PLL} / \mathrm{Au}\right.$ nps) ${ }_{6} /(\mathrm{PLL} / \mathrm{Hep})_{6} / \mathrm{bFGF}$; 5LA-(PLL/Hep) ${ }_{6} / \mathrm{BMP}-2 /(\mathrm{PLL} / \mathrm{Au} \text { nps })_{6} /(\mathrm{PLL} / \mathrm{Hep})_{6} / \mathrm{bFGF}$; and 6: negative control for $3,7,10$, and 14 days. The error bars are all SD.

(PLL/Hep) ${ }_{6}$ /bFGF films had the highest Col-I expression at day 14 among all of the studied surfaces, including that of (PLL/Hep) $)_{6} / \mathrm{BMP}-2 /(\mathrm{PLL} / \mathrm{Au} \text { nps })_{6} /(\mathrm{PLL} / \mathrm{Hep})_{6}$ and (PLL/ $\mathrm{Hep})_{6} /(\mathrm{PLL} / \mathrm{Au} \text { nps })_{6} /(\mathrm{PLL} / \mathrm{Hep})_{6} / \mathrm{bFGF}$ (Figures 9 and $\mathrm{S} 3)$. The data suggested that the co-immobilized growth factors by the heparined nanocomposite films had synergistically enhanced the osteogenic differentiation of MSCs. The synergistic effect of the immobilized BMP-2 and bFGF might be achieved by the mutual regulation of signaling pathways. ${ }^{43}$

\section{CONCLUSIONS}

In this study, $\mathrm{Hep} / \mathrm{Au}$ nanocomposite films were constructed to deliver BMP-2 and bFGF dually for osteogenic differentiation of MSCs. The developed nanocomposite films were characterized separately by UV-vis spectroscopy, XPS analysis, $\mathrm{AFM}, \mathrm{QCM}$, and the nanoindentation technique. The cell viability of MSCs on the developed films was evaluated, including PLA-(PLL/Hep) $)_{6} / \mathrm{BMP}-2 /(\mathrm{PLL} / \mathrm{Au} \mathrm{nps})_{6} /(\mathrm{PLL} /$ Hep $)_{6}$, PLA-(PLL/Hep $)_{6} /(\mathrm{PLL} / \mathrm{Au} \text { nps })_{6} /(\mathrm{PLL} / \mathrm{Hep})_{6} /$ bFGF, and PLA-(PLL/Hep $)_{6} / \mathrm{BMP}-2 /(\mathrm{PLL} / \mathrm{Au} \text { nps })_{6} /(\mathrm{PLL} /$ Hep $)_{6} /$ bFGF, and they all showed low cytotoxicity, which implied that the films were suitable for the investigation of their potential applications in cellular and tissue engineering. During the process of osteogenic differentiation of MSCs, the (PLL/ Hep $)_{6} / \mathrm{BMP}-2 /(\mathrm{PLL} / \mathrm{Au} \text { nps })_{6} /$ (PLL/Hep) ${ }_{6} / \mathrm{bFGF}$ films presented good osteoinductivity with the highest ALP activity and Col-I gene expression, compared with (PLL/Hep) $)_{6} / \mathrm{BMP}-2 /$ $(\mathrm{PLL} / \mathrm{Au} \mathrm{nps})_{6} /(\mathrm{PLL} / \mathrm{Hep})_{6}$ and (PLL/Hep $)_{6} /(\mathrm{PLL} / \mathrm{Au}$ nps $)_{6} /(\mathrm{PLL} / \mathrm{Hep})_{6} / \mathrm{bFGF}$, showing the synergistic effect of both growth factors. Therefore, the heparined film for the synergistic delivery of multiple growth factors is an efficient system. Importantly, this kind of films may serve as potential osteoinductive coatings for biomedical scaffolds in bone tissue 


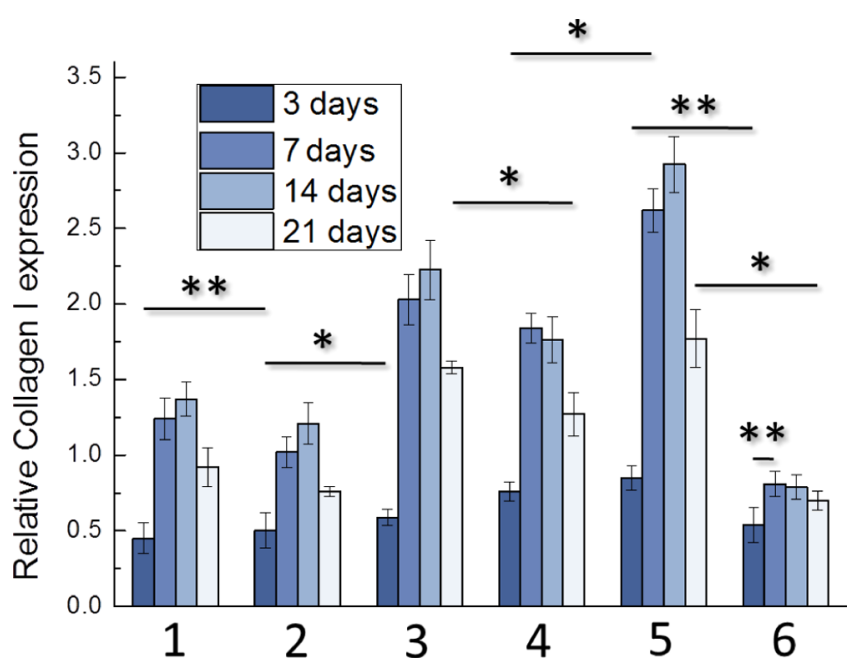

Figure 9. RT-PCR analysis for the expression of collagen I in MSCs on 1: TCPS; $2:$ PLA; 3: PLA-(PLL/Hep $)_{6} / \mathrm{BMP}-2 /(\mathrm{PLL} / \mathrm{Au} \text { nps })_{6} /$ (PLL/Hep) ${ }_{6}$; 4: PLA-(PLL/Hep $)_{6} /(\mathrm{PLL} / \mathrm{Au} \text { nps })_{6} /(\mathrm{PLL} / \mathrm{Hep})_{6} /$ bFGF; 5: PLA-(PLL/Hep) 6 /BMP-2/(PLL/Au nps) $6 /(\mathrm{PLL} / \mathrm{Hep})_{6} /$ bFGF; and 6: negative control after culture for 3, 7, 14, and 21 days. The error bars are all SD.

engineering. Additionally, the strategy can be extended to immobilize other growth factors according to requirements, thus opening an effective way to develop novel types of biomedical surfaces.

\section{EXPERIMENTAL SECTION}

Materials. Polyethyleneimine solution (PEI, $\sim 50 \%$ in $\mathrm{H}_{2} \mathrm{O}$ ), poly-L-lysine hydrobromide (PLL, MW: 30 000-70 $000)$, Hep ammonium salt from porcine intestinal mucosa (17-19 kDa), and bovine serum albumin were all purchased from Sigma-Aldrich (USA). FGF Basic Recombinant Human Protein and BMP-2 Recombinant Human Protein were obtained from Gibco. Chloroauric acid trihydrate $\left(\mathrm{HAuCl}_{4}\right.$. $\left.4 \mathrm{H}_{2} \mathrm{O}, 99.9 \%\right)$ was purchased from Shanghai Sinopharm (China). Trisodium citrate dihydrate $\left(\mathrm{Na}_{3} \mathrm{C}_{6} \mathrm{H}_{5} \mathrm{O}_{7} \cdot 2 \mathrm{H}_{2} \mathrm{O}\right)$ was obtained from Tianjin Kaitong chemical reagent co., Ltd (China). APTT kits were purchased from MACCURA, China. PLA sheets with a thickness of $100 \mu \mathrm{m}$ were purchased from the Institute of Medical Devices of Shandong Province (China). All of the chemical reagents were used as received without further purification. The water used in this work was purified using a Millipore Milli-Q system.

Preparation of Au nps. Au nps were prepared by the classical chemical reduction method, namely, citrate-induced reduction of aqueous $\mathrm{Au}^{3+} .44,45$ That is, in nearly boiling water, the reductant $\mathrm{Na}_{3} \mathrm{C}_{6} \mathrm{H}_{5} \mathrm{O}_{7} \cdot 2 \mathrm{H}_{2} \mathrm{O}$ reduced $\mathrm{Au}^{3+}$ to Au directly. A typical reaction was performed as follows: $40 \mathrm{~mL}$ of $0.25 \mathrm{mM}$ $\mathrm{HAuCl}_{4}$ solution was heated to $95-100{ }^{\circ} \mathrm{C}$, and then $2 \mathrm{~mL}$ of 5 $\mathrm{mg} / \mathrm{mL}$ preheated citrate was added dropwise to it under agitation. When the color of the solution changed slightly from yellow to wine red, the Au np dispersion was boiled for another $30 \mathrm{~min}$, followed by cooling to room temperature before centrifugation ( $8000 \mathrm{rpm}, 10 \mathrm{~min})$. During the preparation, the glassware used was drastically cleaned with aqua regia and water, and then oven-dried at $110{ }^{\circ} \mathrm{C}$ for $2 \mathrm{~h}$.

Fabrication of Composite Multilayer Films. Silicon, quartz wafer, PLA sheet, and QCM electrode were used as the substrates during the LbL assembly for different characterization. Here, PLA sheets were used as the substrates due to the fact that the PLA-based medical implants had been approved by the US Food and Drug Administration for direct contact with biological fluids and had been applied widely in tissue engineering in the form of anchors, screws, plates, pins, rods, and so on. Silicon, quartz wafer, and the gold electrode of QCM were treated by Piranha solution $\left(98 \% \mathrm{H}_{2} \mathrm{SO}_{4}: 30 \% \mathrm{H}_{2} \mathrm{O}_{2}\right.$ $=7: 3, \mathrm{v} / \mathrm{v}$ ) before use. To make the assembly efficiently, PEI was the first layer on the substrates. PLA sheets were treated with poly-(allylamine hydrochloride) to make the surface positively charged. Then, the corresponding substrates were dipped alternatively in Hep solution $(2 \mathrm{mg} / \mathrm{mL}$ in $0.15 \mathrm{M}$ $\mathrm{NaCl})$ and PLL solution $(2 \mathrm{mg} / \mathrm{mL}$ in $0.15 \mathrm{M} \mathrm{NaCl})$, for 20 min for each by washing three times each time until 6-bilayer (PLL/Hep $)_{6}$ coatings were obtained. Continuously, the obtained (PLL/Hep) ${ }_{6}$ surface was used as the new substrate, onto which (PLL/Au nps) 6 was deposited in the same way subsequently. Finally, another (PLL/Hep) 6 multilayer was deposited as the outermost surface.

Growth Factor Loading and Release. First, the BMP-2 solution (200 $\mathrm{ng} / \mathrm{mL}$ in PBS) was dropped onto the film (PLL/Hep) ${ }_{6}$ being incubated for $6 \mathrm{~h}$ to be loaded onto the film, and then, (PLL/Au nps) 6 was deposited further up. Finally, bFGF was loaded onto (PLL/Hep) ${ }_{6} / \mathrm{BMP}-2 /\left(\mathrm{PLL} / \mathrm{Au}\right.$ nps) ${ }_{6} /$ (PLL/Hep $)_{6}$ similarly. In such a way, the (PLL/Hep $)_{6} / \mathrm{BMP}-$ $2 /(\mathrm{PLL} / \mathrm{Au} \mathrm{nps})_{6} /(\mathrm{PLL} / \mathrm{Hep})_{6} / \mathrm{bFGF}$ films were obtained and recorded as $(\mathrm{P} / \mathrm{H})_{6} / \mathrm{BMP}-2 /(\mathrm{P} / \mathrm{A})_{6} /(\mathrm{P} / \mathrm{H})_{6} / \mathrm{bFGF}$ for short.

The loading process of the films with growth factors was monitored using the QCM technique (Q-Sense E4, Biolin Scientific, Sweden). The QCM gold electrode (14 $\mathrm{mm}$ in diameter) was treated with Piranha solution, following by chemical absorption of negatively charged 3-mercapto-1propanesulfonate sodium (Sigma-Aldrich). The charged gold electrode with PEI as the first layer served as the substrate for the construction of films (PLL/Hep) 6 . The as-developed films were incubated with growth factor solution $(200 \mathrm{ng} / \mathrm{mL}$ in PBS) at a flow rate of $50 \mu \mathrm{L} / \mathrm{min}$ continuously until the equilibrium. During the process, the shifts in frequency were continuously recorded.

The released amount of growth factors from these films was determined using enzyme-linked immunosorbent assay kits for BMP-2 and bFGF (Thermo Scientific).

APTT Tests. APTT was used to determine the anticoagulation properties of PLL/Hep multilayers. Here, fresh blood taken from a health volunteer was centrifuged at 3000 rpm for 15 min to obtain PRP for the anticoagulation test. The samples were immersed in $350 \mu \mathrm{L} \mathrm{PRP}$ and incubated at $37^{\circ} \mathrm{C}$ for $30 \mathrm{~min}$. Then $300 \mu \mathrm{L}$ of the treated PRP were moved and mixed with $2.5 \mathrm{~mL}$ APTT reagent in the given storage tanks, similarly for that untreated PRP. Subsequently, thrombus formation was detected automatically by a change in the turbidity of the solution, and the coagulation times were determined using a Sysmex CA-1500 instrument (SIEMENS, Germany).

Characterization of $\mathrm{Au}$ nps and $\mathrm{Au}$ np-Based Composite Films. Au nps were characterized using a $\mathrm{H}$ 7500 transmission electron microscope (TEM, Hitachi, Japan) and a UV-3600 UV-Vis spectroscope (Shimadzu, Japan). The zeta potential of gold nanoparticles was evaluated using a Zetasizer Nano-ZS analyzer (Malvern, U.K.). The assembled films were analyzed through XPS ESCAlab 220i-XL (VG, U.K.) with $\mathrm{Al} \mathrm{K} \alpha$ radiation at an angle of $54.7^{\circ}$ under a pressure of $10^{9}$ mbar. The surface topography and roughness of the multilayer films in the dry state were observed and analyzed 
using a Nanoscope IIIa AFM (Digital Instrument) in the tapping mode using OPUS tips, a standard tapping mode AFM probe (NANOANDMORE, Germany). Nanomechanical tests were carried out with a commercial nanoindenter TS 75 (Hysitron Inc.) using a cube-corner indenter tip with a radius of 40-50 nm. This is a load-controlled and displacement-sensing device. The measurement was performed at $20-25{ }^{\circ} \mathrm{C}$ and under a humidity of about $30 \%$, as previously reported. ${ }^{46}$ The obtained load-displacement curve was utilized to calculate the reductive elastic modulus $\left(E_{\mathrm{r}}\right)$ and hardness $(H)$ of the film samples with the method of Oliver and Pharr. ${ }^{47}$ The $E_{\mathrm{r}}$ and $H$ could be derived from the following equations.

$$
\begin{aligned}
\frac{1}{E_{\mathrm{r}}} & =\frac{2}{S} \sqrt{\frac{A}{\pi}} \\
H & =\frac{P_{\max }}{A} \\
A & =C_{0} h_{\mathrm{c}}^{2}+C_{1} h_{\mathrm{c}}+C_{2} h_{\mathrm{c}}^{1 / 2} \\
& =4.397 h_{\mathrm{c}}^{2}+158.2 h_{\mathrm{c}}+1083.2 h_{\mathrm{c}}^{1 / 2} \\
h_{\mathrm{c}} & =h_{\max }-0.75 \times \frac{P_{\max }}{S}
\end{aligned}
$$

$S$ is the slope of the unloading curve at the maximum penetration depth $h_{\max }$.

Cell Culture. MSCs derived from rat bone marrow were purchased from Tianjin Weikai Bioeng Ltd. (China) and cultured under $5 \% \mathrm{CO}_{2}$ at $37{ }^{\circ} \mathrm{C}$ with Dulbecco's Modified Eagle's Medium supplemented with $10 \%$ fetal bovine serum (Invitrogen) and 1\% penicillin/streptomycin (Invitrogen). The cells at passage 4 were used in the experiments. For comparison, the cells were seeded onto different surfaces, including TCPS, PLA sheets, PLA-(PLL/Hep) ${ }_{6} / \mathrm{BMP}-2 /(\mathrm{PLL} /$ $\mathrm{Au}$ nps $)_{6} /(\mathrm{PLL} / \mathrm{Hep})_{6}$, PLA-(PLL/Hep $)_{6} /(\mathrm{PLL} / \mathrm{Au} \text { nps })_{6} /$ (PLL/Hep $)_{6} / \mathrm{bFGF}$, and PLA-(PLL/Hep $)_{6} / \mathrm{BMP}-2 /(\mathrm{PLL} / \mathrm{Au}$ nps $)_{6} /(\mathrm{PLL} / \mathrm{Hep})_{6} / \mathrm{bFGF}$.

Cell Viability. For cell viability, the cells with a density of $3.0 \times 10^{4}$ cells/well were seeded onto the above surfaces, that is, TCPS, PLA, PLA-(PLL/Hep $)_{6} / \mathrm{BMP}-2 /(\mathrm{PLL} / \mathrm{Au} \text { nps })_{6} /$ (PLL/Hep $)_{6}$, PLA-(PLL/Hep $)_{6} /(\mathrm{PLL} / \mathrm{Au} \mathrm{nps})_{6} /(\mathrm{PLL} /$ Hep $)_{6} / \mathrm{bFGF}$, and PLA-(PLL/Hep $)_{6} / \mathrm{BMP}-2 /(\mathrm{PLL} / \mathrm{Au}$ nps $)_{6} /(\mathrm{PLL} / \mathrm{Hep})_{6} / \mathrm{bFGF}$. Cell counting kit-8 (CCK-8) assays (Dojindo, Japan) were carried out for all of the cells at days 1, 7, 14 and 21. The morphology of the MSCs on different surfaces was obtained using an inverted phase-contrast microscope (Olympus CKX31, Japan) at day 3.

ALP Staining and Activity Assay. The MSCs were seeded onto the studied and control surfaces, including TCPS, PLA, PLA-(PLL/Hep $)_{6} /$ BMP-2/(PLL/Au nps) $)_{6} /(\mathrm{PLL} / \mathrm{Hep})_{6}$, PLA(PLL/Hep $)_{6} /(\mathrm{PLL} / \mathrm{Au} \text { nps })_{6} /(\mathrm{PLL} / \mathrm{Hep})_{6} / \mathrm{bFGF}$, and PLA(PLL/Hep $)_{6} / \mathrm{BMP}-2 /(\mathrm{PLL} / \mathrm{Au} \text { nps })_{6} /(\mathrm{PLL} / \mathrm{Hep})_{6} / \mathrm{bFGF}$ at a density of $1.0 \times 10^{4}$ cells/well in 24-well plates. After $24 \mathrm{~h}$, osteogenesis was induced by replacing the original medium with osteogenic medium containing $10 \mathrm{mM} \beta$-glycerol phosphate, $10^{-8} \mathrm{M}$ dexamethasone, and $0.2 \mathrm{mM}$ ascorbic acid, which would be changed every 3 days up to confluence (21 days). ALP staining was performed using BCIP/NBT stock solution (Beyotime, China) at day 14 and ALP activity assay was carried out by using the protocol from the ALP assay kit (abcam, Hong Kong) at days 3, 7, 10, and 14.
Quantitative RT-PCR. In six-well plates, the MSCs were seeded onto the studied and control surfaces, including TCPS, PLA, PLA-(PLL/Hep) $)_{6} / \mathrm{BMP}-2 /(\mathrm{PLL} / \mathrm{Au} \text { nps })_{6} /(\mathrm{PLL} / \mathrm{Hep})_{6}$, PLA-(PLL/Hep $)_{6} /(\mathrm{PLL} / \mathrm{Au} \text { nps })_{6} /(\mathrm{PLL} / \mathrm{Hep})_{6} / \mathrm{bFGF}$, and PLA-(PLL/Hep $)_{6} / \mathrm{BMP}-2 /(\mathrm{PLL} / \mathrm{Au} \text { nps })_{6} /(\mathrm{PLL} / \mathrm{Hep})_{6} /$ bFGF at a density of $1.0 \times 10^{4}$ cells/well. At days $3,7,14$, and 21, the cells were washed and collected, for RNA extraction using Trizol reagents (Invitrogen). The RNA concentrations were assessed at $260 \mathrm{~nm}$ with a spectrophotometer from Nanodrop 2000 (Thermo Fisher Scientific). The expression of Col-I gene was measured by RT-PCR performance using FastQuant RT Kit (TIANGEN, China) and SuperRealPreMix Plus (TIANGEN, China) on a LightCycler 480 Real-Time PCR System (Roche, Switzerland). The gene expression normalized to GAPDH was expressed and used.

Statistical Analysis. All experiments were repeated at least three times with the data presented as mean \pm SD. Statistical analysis was performed using one-way analysis of variance (ANOVA) and the comparison was made by Tukey's method post hoc test. The differences $* p<0.05, * * p<0.01$ among all samples or between samples and controls were considered statistically significant.

\section{ASSOCIATED CONTENT}

\section{Supporting Information}

The Supporting Information is available free of charge on the ACS Publications website at DOI: 10.1021/acsomega.6b00420.

TEM and DLS of Au np dispersion, MSC proliferation on all studied surfaces, and gel electrophoresis results of mRNA of cells osteoinduced for 14 days on all of the studied surfaces (PDF)

\section{AUTHOR INFORMATION}

\section{Corresponding Authors}

*E-mail: qiwei@mail.qfnu.edu.cn (W.Q.).

*E-mail: huawangqfnu@126.com (H.W.).

ORCID

Wei Qi: 0000-0002-6037-1802

Hua Wang: 0000-0003-0728-8986

Notes

The authors declare no competing financial interest.

\section{ACKNOWLEDGMENTS}

This work was financially supported by the National Nature Science Foundation of China (Nos. 21573126, 21675099) and the Nature Science Foundation of Shandong Province, China (No. ZR2014BM025).

\section{REFERENCES}

(1) Lee, K.; Silva, E. A.; Mooney, D. J. Growth factor delivery-based tissue engineering: general approaches and a review of recent developments. J. R. Soc., Interface 2011, 8, 153-170.

(2) Cross, M.; Dexter, T. M. Growth factors in development, transformation, and tumorigenesis. Cell 1991, 64, 271-280.

(3) Ding, Z.; Fan, Z. H.; Huang, X. W.; Lu, Q.; Xu, W. A.; Kaplan, D. L. Silk-hydroxyapatite nanoscale scaffolds with programmable growth factor delivery for bone repair. ACS Appl. Mater. Interfaces 2016, 8, 24463-24470.

(4) Qu, X.; He, F.; Tan, H.; Yu, Y.; Axrap, A.; Wang, M.; Dai, K.; Zhang, Z.; Yang, F.; Wang, S.; Kohnd, J.; Liu, C. S. Self-assembly of dual drug-delivery coating for synergistic bone regeneration. J. Mater. Chem. B 2016, 4, 4901-4912. 
(5) Bhakta, G.; Rai, B.; Lim, Z. X.; Hui, J. H.; Stein, G. S.; van Wijnen, A. J.; Nurcombe, V.; Prestwich, G. D.; Cool, S. M. Hyaluronic acid-based hydrogels functionalized with heparin that support controlled release of bioactive BMP-2. Biomaterials 2012, 33, 61136122.

(6) Geiger, M.; Li, R. H.; Friess, W. Collagen sponges for bone regeneration with rhBMP-2. Adv. Drug Delivery Rev. 2003, 55, 16131629.

(7) Cai, P.; Xue, Z. Y.; Qi, W.; Wang, H. Adsorbed BMP-2 in polyelectrolyte multilayer films for enhanced early osteogenic differentiation of mesenchymal stem cells. Colloids Surf., A 2013, 434, 110-117.

(8) Ma, C.; Jing, Y.; Sun, H.; Liu, X. Hierarchical nanofibrous microspheres with controlled growth factor delivery for bone regeneration. Adv. Healthcare Mater. 2015, 4, 2699-2708.

(9) Barati, D.; Shariati, S. R. P.; Moeinzadeh, S.; Melero-Martin, J. M.; Khademhosseini, A.; Jabbari, E. Spatiotemporal release of BMP-2 and VEGF enhances osteogenic and vasculogenic differentiation of human mesenchymal stem cells and endothelial colony-forming cells co-encapsulated in a patterned hydrogel. J. Controlled Release 2016, $223,126-136$.

(10) Hettiaratchi, M. H.; Miller, T.; Temenoff, J. S.; Guldberg, R. E.; McDevitt, T. C. Heparin microparticle effects on presentation and bioactivity of bone morphogenetic protein-2. Biomaterials 2014, 35, 7228-7238.

(11) Chapanian, R.; Amsden, B. G. Combined and sequential delivery of bioactive $\operatorname{VEGF}(165)$ and HGF from poly(trimethylene carbonate) based photo-crosslinked elastomers. J. Controlled Release 2010, 143, 53-63.

(12) Freeman, I.; Kedem, A.; Cohen, S. The effect of sulfation of alginate hydrogels on the specific binding and controlled release of heparin-binding proteins. Biomaterials 2008, 29, 3260-3268.

(13) Joung, Y. K.; Bae, J. W.; Park, K. D. Controlled release of heparin-binding growth factors using heparin-containing particulate systems for tissue regeneration. Expert Opin. Drug Delivery 2008, 5, $1173-1184$.

(14) Jia, Y.; Duan, L.; Li, J. B. Hemoglobin-based nanoarchitectonic assemblies as oxygen carriers. Adv. Mater. 2016, 28, 1312-1318.

(15) Cui, W.; Wang, A. H.; Zhao, J.; Yang, X. K.; Cai, P.; Li, J. B. Layer by layer assembly of albumin nanoparticles with selective recognition of tumor necrosis factor-related apoptosis-inducing ligand (TRAIL). J. Colloid Interface Sci. 2016, 465, 11-17.

(16) Keeney, M.; Jiang, X. Y.; Yamane, M.; Lee, M.; Goodman, S.; Yang, F. Nanocoating for biomolecule delivery using layer-by-layer self-assembly. J. Mater. Chem. B 2015, 3, 8757-8770.

(17) Xing, R.; Jiao, T. F.; Ma, K.; Ma, G. H.; Möhwald, H.; Yan, X. H. Regulating cell apoptosis on layer-by-layer assembled multilayers of photosensitizer-coupled polypeptides and gold nanoparticles. Sci. Rep. 2016, 6, No. 26506.

(18) Jiang, F. G.; Yeh, C. K.; Wen, J. C.; Sun, Y. Y. Ntrimethylchitosan/alginate layer-by-layer self assembly coatings act as "fungal repellents" to prevent biofilm formation on healthcare materials. Adv. Healthcare Mater. 2015, 4, 469-475.

(19) Yoshida, K.; Hasebe, Y.; Takahashi, S.; Sato, K.; Anzai, J. Layerby-layer deposited nano- and micro-assemblies for insulin delivery: A review. Mater. Sci. Eng., C 2014, 34, 384-392.

(20) Ariga, K.; Li, J. B.; Fei, J. B.; Ji, Q. M.; Hill, J. P. Nanoarchitectonics for dynamic functional materials from atomic-/ molecular-level manipulation to macroscopic action. Adv. Mater. 2016, 28, 1251-1286.

(21) Rydzek, G.; Ji, Q. M.; Li, M.; Schaaf, P.; Hill, J. P.; Boulmedais, F.; Ariga, K. Electrochemical nanoarchitectonics and layer-by-layer assembly: from basics to future. Nano Today 2015, 10, 138-167.

(22) Qi, W.; Cai, P.; Yuan, W. J.; Wang, H. Tunable swelling of polyelectrolyte multilayers in cell culture media for modulating NIH3T3 cells adhesion. J. Biomed. Mater. Res. A 2014, 102, 4071-4077.

(23) Richardson, J. J.; Björnmalm, M.; Caruso, F. Technology-driven layer-by-layer assembly of nanofilms. Science 2015, 348, No. aaa2491.
(24) Gentile, P.; Carmagnola, I.; Nardo, T.; Chiono, V. Layer-bylayer assembly for biomedical applications in the last decade. Nanotechnology 2015, 26, No. 422001.

(25) Monge, C.; Almodovar, J.; Boudou, T.; Picart, C. Spatiotemporal control of LbL films for biomedical applications: from $2 \mathrm{D}$ to 3D. Adv. Healthcare Mater. 2015, 4, 811-830.

(26) Wang, H.; Zou, Q.; Boerman, O. C.; Nijhuis, A. W. G.; Jansen, J. A.; Li, Y.; Leeuwenburgh, S. C. G. Combined delivery of BMP-2 and bFGF from nanostructured colloidal gelatin gels and its effect on bone regeneration in vivo. J. Controlled Release 2013, 166, 172-181.

(27) Humood, M.; Chowdhury, S.; Song, Y.; Tzeng, P.; Grunlan, J. C.; Polycarpou, A. A. Nanomechanical behavior of high gas barrier multilayer thin films. ACS Appl. Mater. Interfaces 2016, 8, 1112811138 .

(28) Qi, W.; Yuan, W. J.; Yan, J.; Wang, H. Growth and accelerated differentiation of mesenchymal stem cells on graphene oxide/poly-Llysine composite films. J. Mater. Chem. B 2014, 2, 5461-5467.

(29) Qi, W.; Xue, Z. Y.; Yuan, W. J.; Wang, H. Layer-by-layer assembled graphene oxide composite films for enhanced mechanical properties and fibroblast cell affinity. J. Mater. Chem. B 2014, 2, 325331.

(30) Liu, G. Z.; Iyengar, S. G.; Gooding, J. J. An amperometricimmunosensor based on a gold nanoparticle-diazonium salt modified sensing interface for the detection of $\mathrm{HbAlc}$ in human blood. Electroanalysis 2013, 25, 881-887.

(31) Li, J.; Li, J. J.; Zhang, J.; Wang, X. L.; Kawazoe, N.; Chen, G. P. Gold nanoparticle size and shape influence on osteogenesis of mesenchymal stem cells. Nanoscale 2016, 8, 7992-8007.

(32) Li, J. J.; Kawazoe, N.; Chen, G. P. Gold nanoparticles with different charge and moiety induce differential cell response on mesenchymal stem cell osteogenesis. Biomaterials 2015, 54, 226-236.

(33) Yi, C.; Liu, D.; Fong, C.-C.; Zhang, J.; Yang, M. Gold Nanoparticles Promote Osteogenic Differentiation of Mesenchymal Stem Cells through p38 MAPK Pathway. ACS Nano 2010, 4, 64396448.

(34) Lee, J.; Abdeen, A. A.; Zhang, D.; Kilian, K. A. Directing stem cell fate on hydrogel substrates by controlling cell geometry, matrix mechanics and adhesion ligand composition. Biomaterials 2013, 34, $8140-8148$

(35) Jaiswal, A. K.; Chhabra, H.; Soni, V. P.; Bellare, J. R. Enhanced mechanical strength and biocompatibility of electrospunpolycaprolactone-gelatin scaffold with surface deposited nano-hydroxyapatite. Mater. Sci. Eng., C 2013, 33, 2376-2385.

(36) Even-Ram, S.; Artym, V.; Yamada, K. M. Matrix control of stem cell fate. Cell 2006, 126, 645-647.

(37) Engler, A. J.; Sen, S.; Sweeney, H. L.; Discher, D. E. Matrix elasticity directs stem cell lineage specification. Cell 2006, 126, 677689.

(38) Frens, G. Controlled nucleation for the regulation of the particle size in monodisperse gold suspensions. Nat. Phys. Sci. 1973, 241, 2022.

(39) Ji, X.; Song, X. N.; Li, J.; Bai, Y. B.; Yang, W. S.; Peng, X. G. Size control of gold nanocrystals in citrate reduction: the third role of citrate. J. Am. Chem. Soc. 2007, 129, 13939-13948.

(40) Beamson, G.; Briggs, D. High Resolution XPS of Organic Polymers-The Scienta ESCA 300 Data Base; John Wiley \& Sons, Ltd: Chichester, 1992.

(41) Jiang, C.; Markutsya, S.; Tsukruk, V. V. Collective and individual plasmon resonances in nanoparticle films obtained by spin-assisted layer-by-layer assembly. Langmuir 2004, 20, 882-890.

(42) Cui, W.; Cui, Y.; Zhu, P. L.; Zhao, J.; Su, Y.; Yang, Y.; Li, J. B. An anticoagulant activity system using nanoengineered autofluorescent heparin nanotubes. Chem. Asian J. 2012, 7, 127-132.

(43) Maegawa, N.; Kawamura, K.; Hirose, M.; Yajima, H.; Takakura, Y.; Ohgushi, H. Enhancement of osteoblastic differentiation of mesenchymal stromal cells cultured by selective combination of bone morphogenetic protein-2 (BMP-2) and fibroblast growthfactor-2 (FGF-2). J. Tissue Eng. Regener. Med. 2007, 1, 306-313. 
(44) Cao, Y.-C.; Wang, Z.; Jin, X.; Hua, X.-F.; Liu, M.-X.; Zhao, Y.-D. Preparation of $\mathrm{Au}$ nanoparticles-coated polystyrene beads and its application in protein immobilization. Colloids Surf., A 2009, 334, 5358.

(45) Turkevich, J.; Stevenson, P. C.; Hillier, J. A study of the nucleation and growth processes in the synthesis of colloidal gold. Discuss Faraday Soc. 1951, 11, 55-75.

(46) Pavoor, P. V.; Bellare, A.; Strom, A.; Yang, D.; Cohen, R. E. Mechanical characterization of polyelectrolyte multilayers using quasistatic nanoindentation. Macromolecules 2004, 37, 4865-4871.

(47) Tsui, T. Y.; Oliver, W. C.; Pharr, G. M. Influences of stress on the measurement of mechanical properties using nanoindentation: Part I. Experimental studies in an aluminum alloy. J. Mater. Res. 1996, $11,752-759$. 